\title{
Yield of Two Sweet Corn Varieties and Two Hybrids in the Isabela Area ${ }^{1}$
}

\author{
Gerardo Mangual-Crespo ${ }^{2}$
}

\begin{abstract}
Seasonal plantings of two sweet corn varieties and two hybrids were established at the Isabela Agricultural Experiment Substation during $1972-$ 74. In 1972-73, hybrid Hawaii 68 produced the highest marketable yield of 49,289 ears/ha when planted on Dec. 21 (winter planting) and 45,245 when planted on Sept. 21 (autumn planting). The highest marketable yield of the Hawaiian Hybrid when planted on Sept. 21 was 33,570 ears/ha, whereas, PR 50 yielded 36,489 and 31,885 marketable ears when planted on Sept. 21 and Dec. $21,1972-73$, respectively. USDA 34 produced its highest marketable yields in the Sept. 21 plantings, with 31,774 in 1972-73 and 23,129 in 197374.
\end{abstract}

\section{INTRODUCTION}

Sweet corn (Zea mays var, rugosa) is not grown as a commercial crop in Puerto Rico. Fresh field corn, which is planted throughout the year, is generally used in the milk stage in lieu of sweet corn. Field corn sales during 1972-73, as reported by the Commonwealth Department of Agriculture $^{3}$ amounted to 493,000 ears with a wholesale value of $\$ 33,680$. Sales increased in $1973-74$ to 628,000 ears with a value of $\$ 46,741$.

The increasing per capita income in Puerto Rico, coupled with the increase in population and the development of more sophisticated food habits, may contribute to the fostering of large-scale commercial sweet corn plantings for local fresh consumption and possibly for export to the United States during the winter months.

During 1971, Domenech and Mangual ${ }^{4}$ obtained a higher number of marketable ears/ha from hybrid Hawaii 68 as compared to other varieties and hybrids under trial, throughout 12 monthly plantings. The four superior varieties and hybrids of this study have been included in the work reported here.

\section{MATERIALS AND METHODS}

Seasonal plantings of two varieties and two hybrids of sweet corn were established at the Isabela Agricultural Substation during 1972-73 and

' Manuscript submitted to Editorial Board October 31, 1974.

${ }^{2}$ Research Assistant, Agricultural Experiment Station, Mayagüez Campus, University of Puerto Rico, Río Piedras, P.R.

${ }^{3}$ Boletín Mensual de Estadísticas Agrícolas, Departamento de Agricultura de P.R. 14(6): 291, junio 1974 .

${ }^{4}$ Domenech, J., and Mangual, G., Performance of sweet corn varieties and their response to planting season, J. Agr. Univ. P.R. 61(2): 170-4, 1977. 
1973-74. Varieties USDA 34 and PR 50, and hybrids Hawaiian Hybrid and Hawaii 68 were planted in a Coto clay, an Oxisol (Tropectic Haplorthox) during March 21, June 21, September 21, and December 21 in complete block designs with four replications. Seed was sown by hand, $30 \mathrm{~cm}$ apart in rows $6 \mathrm{~m}$ long and $90 \mathrm{~cm}$ wide. Dacthal $75 \mathrm{~W}^{5}$ was used as a pre-emergence herbicide at the rate of $11.25 \mathrm{~kg} / \mathrm{ha}$ of active ingredient. A weekly preventive spraying program was followed to reduce possible insect and disease damage using Diazinon AF 500 and Dithane M-45 at the rates of $1,200 \mathrm{ml}$ and $2.25 \mathrm{~kg} / \mathrm{ha}$, respectively. A 10-10-8 fertilizer was applied at the rate of $2,272 \mathrm{~kg} / \mathrm{ha}$ in bands right after planting.

Irrigation was applied immediately after seeding and subsequently as needed. Sprinkle irrigation was used when plants were small, but as they grew taller, furrow irrigation was used. Rainfall and temperature data during 1972-74 were recorded.

Harvest was started when the ears attained full size, with tight husks and the silk beginning to turn a dark brown color. This usually occurred 65 to 70 days after planting.

Commercial yields were based on ears free of insects and diseases, 13 $\mathrm{cm}$ or more in length, and with well-developed plump, milky kernels. ${ }^{6}$

\section{RESULTS AND DISCUSSION}

Rainfall and temperature were similar during 1972-73 and 1973-74.

Table 1 presents data on total and marketable yields obtained both in 1972-73, and 1973-74. In the 1972-73 planting, Hawaii 68 produced the highest marketable yield when planted on Dec. 21, with 49,289 ears/ha. Variety USDA 34 had the lowest, with 19,649 ears/ha, when planted the same date. With regard to the mean marketable yield, of all four cultivars the autumn planting was the best with a mean of 36,770 ears/ ha., while the summer planting seemed to be the worst with 22,287 ears/ ha. Total and marketable yields obtained during 1973-74 again showed that Hawaii 68 produced the highest marketable yield with 34,130 ears/ ha when planted on March 21, while variety USDA 34 was the lowest yielder with only 9,769 ears/ha when planted on Dec. 21.

In the 1973-74 planting the mean marketable yield, of all four cultivars in the spring planting was the best, with 23,774 ears/ha; the summer planting appeared as the worst, with 20,462 ears/ha. The

5 Trade names are used in this publication solely for the purpose of providing specific information. Mention of a trade name does not constitute a guarantee or warranty of equipment or materials by the Agricultural Experiment Station of the University of Puerto Rico or an endorsement over other equipment or materials not mentioned.

${ }^{6}$ Sims, W. L., Kasmire, R. F., and Lorenz, O. D., Quality sweet corn production, California Agr. Exp. Sta. Cir. 557, 1972. 
TABLE 1. - Total and marketable yields, ears/ha, of two sweet corn varieties and two hybrids planted seasonally at the Isabela Substation

\begin{tabular}{|c|c|c|c|c|c|c|c|c|}
\hline \multirow{2}{*}{ Variety } & \multicolumn{2}{|c|}{ March 21 (spring) } & \multicolumn{2}{|c|}{ June 21 (summer) } & \multicolumn{2}{|c|}{ September 21 (autumn) } & \multicolumn{2}{|c|}{ December 21 (winter) } \\
\hline & Total & Marketable & Total & Marketable & Total & Marketable & Total & Marketable \\
\hline \multicolumn{9}{|c|}{$1972-73$} \\
\hline USDA 34 & $41541 c^{1}$ & $23354 \mathrm{~b}$ & $50299 \mathrm{~b}$ & $20659 \mathrm{ab}$ & $41990 \mathrm{~cd}$ & $31774 \mathrm{~b}$ & $49289 \mathrm{c}$ & $19649 \mathrm{~cd}$ \\
\hline PR 50 & $41205 \mathrm{c}$ & $27844 \mathrm{~b}$ & $50635 \mathrm{~b}$ & $23129 a b$ & $47715 \mathrm{bc}$ & $36468 \mathrm{ab}$ & $54115 \mathrm{~b}$ & $31885 \mathrm{~b}$ \\
\hline Hawaiian Hybrid & $52994 \mathrm{~b}$ & $22455 \mathrm{~b}$ & $50746 \mathrm{~b}$ & $16055 \mathrm{~b}$ & $59280 \mathrm{ab}$ & $33570 \mathrm{ab}$ & $58944 \mathrm{~b}$ & $25935 \mathrm{bd}$ \\
\hline Hawaii 68 & 59841 a & $38060 \mathrm{a}$ & 58045 a & 29304 a & 60965 a & $45245 \mathrm{a}$ & 76795 a & $49289 \mathrm{a}$ \\
\hline Mean & 48895 & 27928 & 52431 & 22287 & 52488 & 36770 & 59786 & 31690 \\
\hline \multicolumn{9}{|c|}{$1973-74$} \\
\hline USDA 34 & 36600 & $16729 \mathrm{c}$ & 56360 & $20096 \mathrm{~cd}$ & 53216 & 23129 a & 46145 & $9769 \mathrm{c}$ \\
\hline PR 50 & 55686 & $26834 \mathrm{ab}$ & 55800 & 21669 ac & 51420 & 22791 a & 61189 & $29751 \mathrm{a}$ \\
\hline Hawaiian Hybrid & 52320 & $17401 \mathrm{c}$ & 49064 & $15944 \mathrm{bd}$ & 50410 & $17401 \mathrm{~b}$ & 55686 & $20884 \mathrm{~b}$ \\
\hline Hawaii 68 & 74100 & 34130 a & 53890 & 24139 a & 67026 & 24364 a & 75560 & $26046 \mathrm{ab}$ \\
\hline Mean & 54677 & 23774 & 53779 & 20462 & 55518 & 21921 & 59645 & 21613 \\
\hline
\end{tabular}

${ }^{1}$ Values in the column, during the same year, followed by one or more letters in common do not differ significantly at the $5 \%$ level. 
differences between seasonal plantings were not statistically significant.

Table 2 shows the percentages of marketable ears obtained for the various crops. Marketable yield, instead of the percentage of marketable ears, should be the determining criterion in the selection of a variety or a hybrid. However, percentages of marketable ears provide an idea of the proportion of marketable yield in each harvest. Some of the 1972-73 percentages were encouraging (table 2), but not so in 1973-74 when the highest percentage obtained was only 49.

Hybrid Hawaii 68 was the best yielder of total ears in the 1972-73 winter (Dec. 21) planting with a total of 76,795 ears/ha, of which 49,289 were marketable (64\%). In the 1973-74 winter (Dec. 21) planting, it reached a peak production of 75,560 total ears/ha, of which 26,046 (34\%) were marketable.

TABLE 2.-Percentages of marketable ears of two varieties and two hybrids of sweet corn planted seasonally at the Isabela Substation, 1972-74

\begin{tabular}{|c|c|c|c|c|c|c|c|c|}
\hline \multirow{2}{*}{ Planting date } & \multicolumn{2}{|c|}{ USDA 34} & \multicolumn{2}{|c|}{ PR 50} & \multicolumn{2}{|c|}{ Hawaiian Hybrid } & \multicolumn{2}{|c|}{ Hawaii 68} \\
\hline & $\begin{array}{c}1972- \\
73\end{array}$ & $1973-74$ & $\begin{array}{c}1972- \\
73\end{array}$ & $1973-74$ & $\begin{array}{c}1972- \\
73\end{array}$ & $1973-74$ & $\begin{array}{c}1972- \\
73\end{array}$ & $\begin{array}{c}1973- \\
74\end{array}$ \\
\hline & \multicolumn{2}{|c|}{$\%$} & \multicolumn{2}{|c|}{$\%$} & \multicolumn{2}{|c|}{$\%$} & \multicolumn{2}{|c|}{$\%$} \\
\hline Mar. 21 (spring) & 56 & 46 & 68 & 48 & 42 & 33 & 61 & 21 \\
\hline June 21 (summer) & 41 & 36 & 46 & 39 & 32 & 33 & 51 & 49 \\
\hline Sept. 21 (autumn) & 76 & 43 & 76 & 44 & 57 & 35 & 74 & 38 \\
\hline Dec. 21 (winter) & 40 & 21 & 59 & 49 & 44 & 38 & 64 & 34 \\
\hline
\end{tabular}

In terms of marketable yields, variety PR 50 was the second best in the 1972-73 September and December plantings and in the 1973-74 December planting.

\section{RESUMEN}

Siembras estacionales de dos variedades y dos híbridos de maíz dulce se establecieron en la Subestación Experimental Agrícola de Isabela durante 1972-74.

El híbrido Hawaii 68 produjo el rendimiento más alto de mazorcas comerciales en el 1972-73 con 49,289 por hectárea, mientras que la variedad USDA 34 produjo el rendimiento comercial menor con 19,649. La variedad PR 50 fue la segunda en producción en las siembras de septiembre 21 (otoño) y diciembre 21 (invierno) de 1972-73 y en la de diciembre de 1973-74.

El mejor rendimiento comercial de los cuatro cultivares en el 1972-73 se obtuvo en la siembra de septiembre 21 (otoño) con un promedio de 36,770 mazorcas por hectárea, mientras que la de verano (junio 21) fue la peor con 22,287 .

En 1973-74, el híbrido Hawaii 68 fue el de mayor rendimiento comercial con 34,130 mazorcas por hectárea cuando se sembró en marzo 21, mientras que la USDA 34 fue la peor con solamente 9,769 en la siembra de diciembre 21 .

La siembra de marzo 21 (primavera) fue la mejor en 1973-74 con un rendimiento medio para los cuatro cultivares de 23,774 mazorcas por hectárea, mientras que la de junio 21 (verano) fue la peor con 20,462 . 